\title{
Ezrin is required for adhesion and migration in invasive breast cancer
}

\author{
Alvin Szeto ${ }^{1,2^{*}}$, Victoria Hoskin ${ }^{1,2}$, Bruce E Elliott ${ }^{1,2}$ \\ From São Paulo Advanced School of Comparative Oncology \\ Águas de São Pedro, Brazil. 30 September - 6 October 2012
}

\section{Background}

Deregulation of focal adhesion (FA) dynamics has been found to contribute to tumour progression by promoting cancer cell migration and invasion. Both focal adhesion kinase (FAK) and Src are involved in FA formation, and both interact with the scaffolding protein ezrin, which our group has shown to be required for breast cancer metastasis. Our aim was to assess the role of the membrane-cytoskeletal linker protein ezrin in Src-induced adhesion and migration in the human invasive breast cancer cell line MDA-MB-231.

\section{Materials and methods}

shRNA-mediated knockdown (KD) of ezrin function was conducted in MDA-MB-231 cells, as well as in cells expressing constitutively active Src (MDA-Src). Adhesion and migration were assessed using collagen-I adhesion assays and wound healing assays, respectively. Expression and localization of FA proteins was assessed via immunoblotting and immunofluorescence (IF).

\section{Results}

Ezrin KD impaired migration of both MDA-MB-231 and MDA-Src cells. Interestingly, Ezrin KD resulted in increased cell adhesion to collagen-I, an extracellular matrix protein found in stromal tissue. IF imaging of the FA-associated proteins $\beta 1$ integrin, FAK, paxillin, and vinculin revealed an increase in localization of these proteins to FA sites at the cell periphery in ezrin KD cells compared to control cells. Furthermore, immunoblotting analysis showed increases in protein expression of $\beta 1$ integrin, FAK and paxillin but not vinculin, suggesting that FA formation may be increased when ezrin expression is abolished.

\section{Conclusions}

Ezrin is required for adhesion and migration of MDAMB-231 cells, and may play an important regulatory role in FA dynamics.

\section{Financial support}

Canadian Institutes of Health Research (BEE), Ontario Graduate Scholarship (AS), Terry Fox Foundation Training Studentship in Transdisciplinary Cancer Research (AS) and Canadian Breast Cancer Foundation Fellowship (VH).

\section{Author details}

'Division of Cancer Biology and Genetics, Queen's Cancer Research Institute, Kingston ON, Canada. ${ }^{2}$ Department of Pathology and Molecular Medicine, Queen's University, Kingston, ON, Canada.

Published: 4 April 2013

doi:10.1186/1753-6561-7-S2-P4

Cite this article as: Szeto et al.: Ezrin is required for adhesion and migration in invasive breast cancer. BMC Proceedings 2013 7(Suppl 2):P4

\footnotetext{
* Correspondence: elliottb@queensu.ca

'Division of Cancer Biology and Genetics, Queen's Cancer Research Institute, Kingston ON, Canada

Full list of author information is available at the end of the article
}

(c) 2013 Szeto et al; licensee BioMed Central Ltd. This is an Open Access article distributed under the terms of the Creative Commons 